\title{
声帯囊胞の臨床統計
}

\author{
田中 康政・田中 信三・畺田 友明 \\ 鹿毛 純子・平野実

\section{Vocal Fold Cyst} \\ - Retrospective Study of 75 Cases for 10 Years - \\ Yasumasa Tanaka, Shinzo Tanaka, Tomoaki Sanada, \\ Sumiko Kage and Minoru Hirano \\ (Kurume University)
}

\begin{abstract}
Seventy-five patients with vocal fold cyst who visited our clinic between 1981 and 1990 were studied. Almost half of the cases were male and $83 \%$ were between thirty and seventy years of age. Only two cases were younger than twenty years of age. Surgery was performed for 38 patients and $97 \%$ of those patients showed vocal improvement after surgery. Vocal function tests and acoustic analyses revealed significant improvements after surgery. There was no difference in results between the complete removal of the cyst with preservation of vocal fold epithelium and removal of the superficial cyst wall covered by vocal fold epithelium. Recurrence occurred in only one case after surgery.
\end{abstract}

Key words: vocal fold cyst, retrospective study, surgery, functional results

はじめに

声帯霊胞の臨床統計については，すでに多く の報告1) 4) があり，当教室でも Kawasaki ら5) が，1971年から1980年までの10年間について報 告している. 本報告では1981年から1990年まで の10年間に久留米大学医学部耳鼻咽喉科外来に 受診した声帯霊胞の患者の臨床統計について検 討を行った。 また，このらち入院し，手術を施 行した患者については, 手術前後の発声機能损 よび音響分析について検討を行った. 声帯塞胞 の理想的な手術法は, 巽胞だけを摘出すること であるが(6) 8), 霊胞壁が薄い場合, 必ずしも理

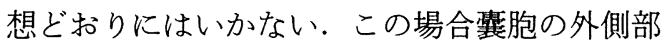

とそれを被う粘膜を鈷除あるいは切除する8).

褧胞を摘出できた症例と鉗除あるいは切除した 症例で術後の発声機能, 音響分析に差があるか 否か検討を行った。

\section{研究対象亡方法}

1981年から1990年までの10年間に久留米大学 医学部耳鼻咽喉科外来を受診し, 声帯霊胞と診 断した75症例を対象とした。またこれらのなか で，入院し手術を行った38症例（51\%）のらち 術前, 術後の発声機能, 音響分析のデータの得 られた 24 症例について手術効果の検討を行った。 手術は，全例全身麻酔下に喉頭微細手術を施行 し, その方法は, 平野ら778) の述べる方法に準 
じて全摘出を目標としたが，貯留霊胞のように 鸾胞壁が脆弱で破れる場合には，平野8)の述べ る次善の策にしたがった（図 1)。手術を施行 した24例のらち，図 1-Aで示す如く完全摘出 を行った症例は17例，図1-Bで示す次善の策 に従って鉗除あるいは切除した症例は 7 例であ った.

発声機能は, 永島 PS-77H を用い最長発声持 続時間 $(\mathrm{MPT})$, 楽な発声時の平均呼気流率 (MFR), 基本周波数 (FO), 声の強さ (SPL), 声 の高さ域 (FOR), 声の強さ域 (SPLR), 音響分 析は，リオン社製 $\mathrm{SH}-10$ を用いて基本周期の 変動率 $(\mathrm{PPQ})$, 振幅の変動率 $(\mathrm{APQ})$, 規格化雑 音エネルギー (NNEa, NNEb) について調べた.

発声機能検査, 音響分析の術前, 術後の有意 差については, paired-T 検定にて検討した.

また，完全摘出群と鉗除群の 2 群間の改善度の 差についても検討した. MPT, MFR, PPQ, $\mathrm{APQ}, \mathrm{NNEa}, \mathrm{NNEb}$ では, 改善度を,

$<$ 改善度 $>=\log$ (術後值) $-\log$ (術前值)

で, FOR, SPLR は, 改善度を,

$<$ 改善度 $>=$ (術後値 $)-($ 術前値 $)$

を用いて求め，これらより 2 群間の改善度に差 があるか否か Wilcoxon の順位和検定を行い検 討を行った.

\section{結 果}

1 ) 年度別度数, 性, 年齢分布, 主訴, 患側
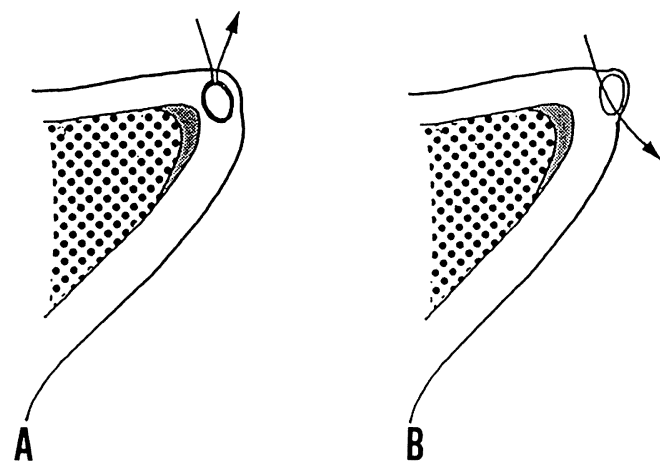

図 1 声帯裂胞手術術式
$\mathrm{A}$ : 完全摘出
B：鉗除あるいは切除

声帯囊胞の年度別受診患者数を, 表 1 に示す. 前半の 5 年間と後半の 5 年間の患者数を比較す ると75例中，前半は 23 例 $31 \%$ ，後半は 52 例 $69 \%$ と増加傾向がみられた。

表 2 に症例の年齢分布を示す. 症例は， 8 歳 から76歳までであり，75例中男性が36例48\%， 女性 39 例 $52 \%$ であった. 症例数は40歳代が一番 多く，50歳代，60歳代がそれに続いていた。

患側は左側26例, 右側42例, 両側 7 例で, 右 側に多い傾向にあった。

主訴は，75例中72例が嗄声を，2例が発声困 難を訴え，1例が喉頭部痛を訴えて来院した。 嗄声の程度は軽度から中等度までであった。

表 1 声帯慗胞の年度別症例数

\begin{tabular}{c|c|c|c|c}
\hline \hline 年度 & 男性 & 女性 & 合計 & 比率 (\%) \\
\hline 1981 & 2 & 2 & 4 & 5 \\
1982 & 0 & 1 & 1 & 1 \\
1983 & 1 & 2 & 3 & 4 \\
1984 & 4 & 2 & 6 & 8 \\
1985 & 3 & 6 & 9 & 12 \\
1986 & 3 & 5 & 8 & 11 \\
1987 & 7 & 5 & 12 & 16 \\
1988 & 9 & 5 & 14 & 19 \\
1989 & 3 & 9 & 12 & 16 \\
1990 & 4 & 2 & 6 & 8 \\
\hline 合 計 & 36 & 39 & 75 & 100
\end{tabular}

表 2 声帯巽胞の年齢分布

\begin{tabular}{c|c|c|c|c}
\hline \hline 年 齢 & 男性 & 女性 & 合計 & 比率 $(\%)$ \\
\hline $0 \sim 9$ 歳 & 1 & 0 & 1 & 1 \\
$10 \sim 19$ & 0 & 1 & 1 & 1 \\
$20 \sim 29$ & 1 & 7 & 8 & 11 \\
$30 \sim 39$ & 2 & 8 & 10 & 13 \\
$40 \sim 49$ & 11 & 9 & 20 & 27 \\
$50 \sim 59$ & 10 & 6 & 16 & 21 \\
$60 \sim 69$ & 9 & 7 & 16 & 21 \\
$70 \sim 79$ & 2 & 1 & 3 & 4 \\
\hline 合 計 & 36 & 39 & 75 & 100
\end{tabular}


2 ) 治療効果

治療効果についてみると, 自覚的改善度は, 手術を施行した38例中，正常に改善したと判断 されたもの30例 $(79 \%)$ ，正常ではないが改善 したもの 7 例 $(18 \%)$ ，不变 1 例 $(3 \%)$ であ った.

発声機能検査, 音響分析の術前術後の值を図 2,3 に示寸. 発声機能検査, 音響分析の術前 後の有意差について, 手術を行った24例では,
MPT, MFR，FOR，SPLR で術前より術後が 有意な改善を認めた。音響分析の結果, $\mathrm{PPQ}$, $\mathrm{APQ}, \mathrm{NNEa}, \mathrm{NNEb}$ ともに有意の改善を認め た。

完全摘出群と，鉗除群の 2 群間の改善度の差 について，Wilcoxon の順位和検定を行い各パ ラメータとも 2 群間に明らかな有意差は認めな かった。

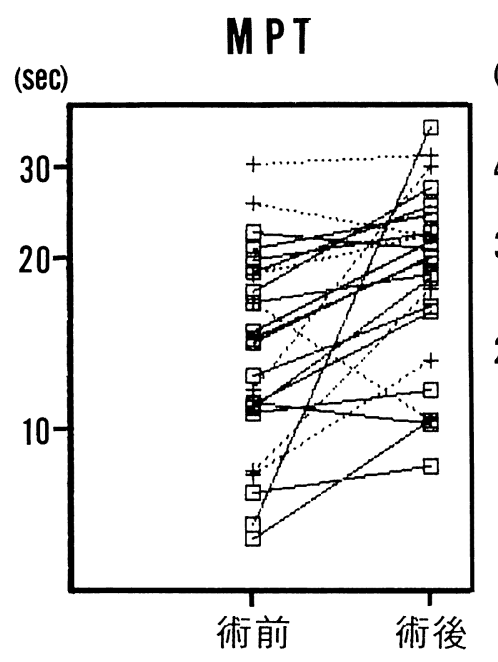

FoR

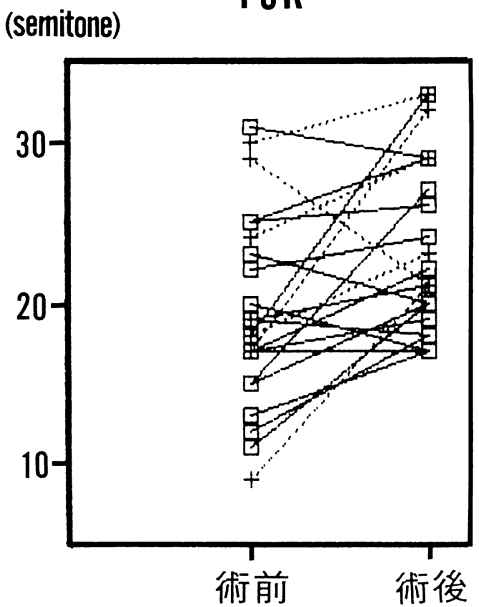

MFR

$(\mathrm{ml} / \mathrm{sec})$

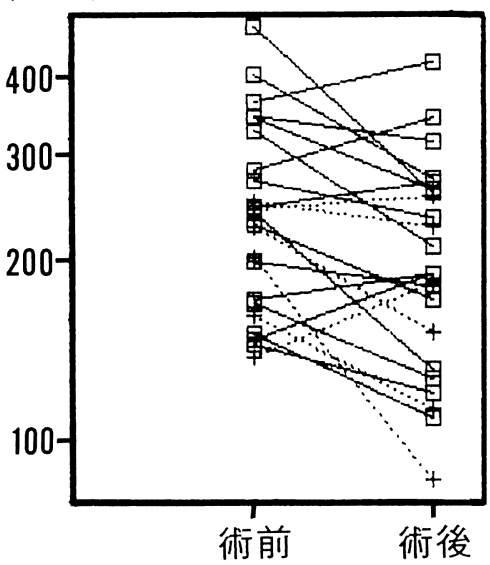

\section{SPLR}

(dB)

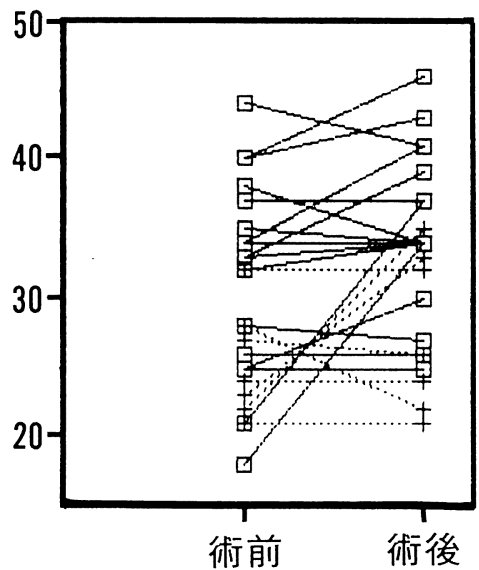

図 2 術前・術後の発声機能

MPT ・ MFR · FOR - SPLR を示す.

$\square$ : 完全摘出症例

+ : 鎮除あるいは切除例 
3 ) 再 発

38 例の手術施行例のうち 5 力月以上長期経過 観察できたのは26例であった。これらの中で, 初回手術の最初の段階で囊胞壁を破ったため囊 胞の再発を待って再手術を行った症例が 1 例あ った. この症例以外, 手術後に再発を認めたも のはなかった。

\section{考察}

本報告は，Kawasaki ら5)の報告した1971年 から1980年までの報告に続く一連の報告である. Kawasaki ら5)の報告では，1970年代の10年間 に声帯霊胞患者は43例であり，本報告の1980年 代では75例と 1.7 倍に増加し, 年度別症例数を みても1990年を除いて年々増加の傾向が認めら

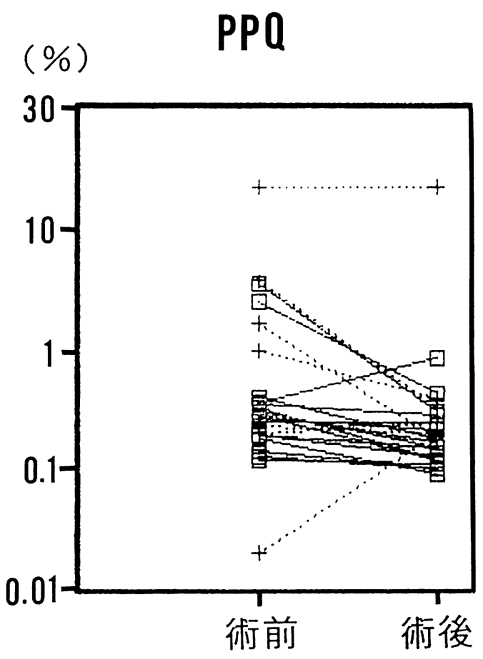

(\%) $\quad \mathrm{APQ}$

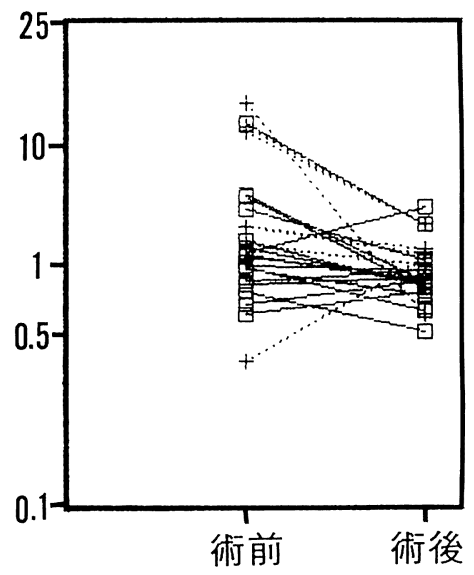

(dB) NNEa

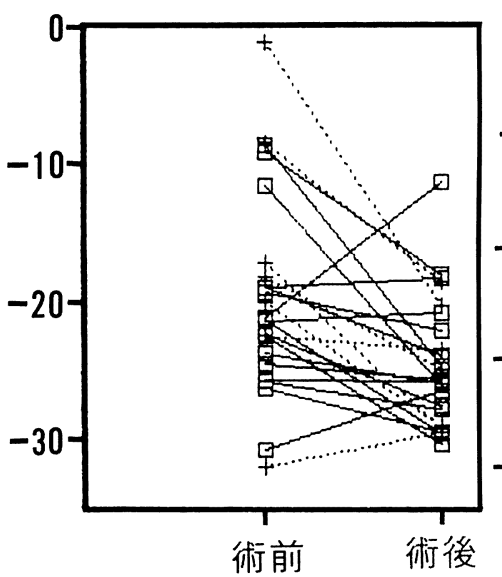

\section{(dB) NNEb}

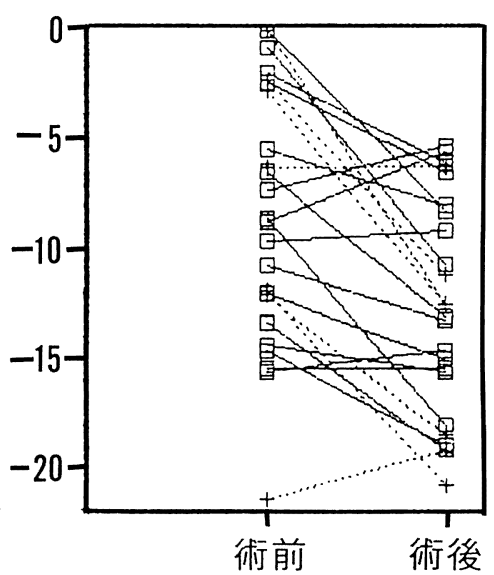

図 3 術前 - 術後の音響分析結果

$\mathrm{PPQ} \cdot \mathrm{APQ} \cdot \mathrm{NNEa} \cdot \mathrm{NNEb}$ を示す.

$\square$ : 完全摘出症例

+ : 鉗除あるいは切除例 
れる.これは, 近年のファイバーストロボやビ デオシステムなどの診断機器の進歩とともに, 医師への啓蒙の効果により豊胞の発見率が上昇 したためと考えられる。

声帯霊胞の男女別の頻度については，Kawasaki ら5) は男性60\%, 女性40\% と述べている。 浜口ら ${ }^{1)}$ は, 男性 $81 \%$ ，女性19\%，田村ら 31 は, 男性76\%，女性24\%で男性の汪らが女性よりも 多いと述べている．今回の我々の報告では, 1980年代の 10 年間では, 男性 $48 \%$, 女性 $52 \%$ で 差はない。

また年齢別に頻度をみると, 浜口ら ${ }^{1)}$, Kawasaki ら5)は，ともに50歳代，60歳代に多いと述べて いるが，我々の統計では，40歳代に一番多く, つぎに50歳代と60歳代が同程度に認められた.

治療として, 手術を行った症例は, Kawasaki ら5)によると1970年代では，43例中 25 例 $58 \%$ で あったが，1981年から1990年までの10年間で75 例中38例 $51 \%$ で，あまり差は認められなかっ た.このよらに手術的治療を受ける比率が少な かったのは，自覚症状が比較的軽度である事と， 悪性疾患ではないために入院手術を希望しない 症例が比較的に多いためと考えられた。

手術治療の効果について検討する. 手術を行 った38例のらち37例が術前に比べ改善を認め,

1 例が術前と不変と答えている．この 1 例は, 霊胞が小さかった事と, 声帯溝症が存在したた めと考兄らた。

手術を施行し, 術前, 術後の発声機能, 音響 分析のデータの得られた24例の MPT, MFR, FOR, SPLR, PPQ, APQ, NNEa, NNEb で改 善を認めている.

手術は, 平野ら 7)8)の述べる如く囊胞の完全 摘出を目的とする。 しかも Reinke space への 手術的侵襲を極力少なくする．これは，術後の 瘢痕による音声の悪化を予防するためであるが， 上皮が薄いため摘出は，大変困難なことがある. このようなとき, 平野8)の述べる次善の策にし たがらが，このような完全摘出を行った症例と， 鉗除もしくは切除を行った症例で, 術後の発声
機能と音響分析の結果に差があるか否か調べた。 その結果, 両群間に差は認められなかった。

再発についてみると, 手術の初期の段階で囊 胞を破ったために手術を中止し再発を待った 1 例以外は再発を認めなかった。これは, 鉗除し た症例のほとんどが，声帯縁に存在する貯留輫 胞であったためと考えられる.声帯上面に接す る epidermoid cyst の場合の鈷除例がほとんど ないので，鉗除しても再発が少ないものか否か 明らかでない、豊胞を破ったのみでは，再発を 扣こすことから不完全な鉗除は，再発をひき㧤 こすものと考觉る.

完全摘出を行った症例と, 鉬除した症例の術 後の機能に有意差がなければ，術式としてどち らの方法をとっても良いと考兄られるが，完全 摘出を行って再発の可能性がないら充に声の改 善が認められるのであれば，それが嗄声を主訴 とする声帯囊胞の患者にとって一番最良の方法 であると考觉る。

$$
\text { まとめ }
$$

1981年から1990年までの10年間に久留米大学 医学部耳鼻咽喉科外来を受診した声帯霊胞の患 者75例について臨床統計とその治療効果につき 検討を行った。 その結果以下のことが解った。

1. 声帯霊胞患者は, 医師の霊胞への認識の 向上と, 診断技術の進歩に伴って年々増 加する傾向にあった。

2. 発生頻度は, 男女ほ核同数であった。

3. 年代別頻度は, 40歳代に多い傾向にあっ た。

4. 手術的治療により有意に声の改善を認め た。

5. 完全摘出と鉗除（切除）では, 術後の改 善度に明らかな差は認めなかった。

\section{文献}

1）浜口 健, 斎藤洋三, 奈良哲次, 他: 声帯粘液 踖留翼腫症例 一本邦文献的ならびに病理組織 学的考察一. 耳喉 $38: 521 \sim 525,1966$.

2）中沢明彦, 古賀郁彦: 声帯上皮整胞症例. 耳喉 35 : 55 58, 1969. 
3）田村宏之, 斉藤成司，鈴木理文，他：声帯票胞 一Laryngomicrosurgeryによる治療一。日気食 会報 $24: 76 \sim 79,1973$.

4) Bouchayer M, Cornut G, Witzig E, et al : Epidermoid cysts, sulci, and mucosal bridges of the true vocal cord; a report of 157 cases. Laryngoscope $95:$ 1087 1094, 1985.

5) Kawasaki H, Kuratomi K, Mitsumasu T, et al : Cysts of the larynx ; a 10-year review of 94 patients. Auris Nasus Larynx (Tokyo) 10 Suppl : 47 52, 1983.

6）平野 実: 音声外科の基礎と臨床. 耳鼻 21
:239 440, 1975.

7) Hirano $M$, Yoshida $T$, Hirade $Y$, et al : Improved surgical technique for epidermoid cysts of the vocal fold. Ann Otol Rhinol Laryngol $98: 791 \sim 795,1989$.

8) 平野 実: 声帯襄胞. JOHNS 8:465 467, 1992.

$$
\left(\begin{array}{l}
\text { 別刷請求先 : 田中康政 } \\
\text { T8 } 830 \text { 久留米市旭町 } 67 \\
\text { 久留米大学医学部耳鼻咽喉科学教室 }
\end{array}\right)
$$

